\title{
Impediments to the Development of a Strong Consumer Credit System in Nigeria
}

\author{
Mokutima Ekpo ${ }^{1}$, Eni Alobo ${ }^{1,2, *} \&$ Jacob Enyia $^{1}$ \\ ${ }^{1}$ Faculty of Law, University of Calabar, Nigeria \\ ${ }^{2}$ Faculty of Law, University of Port Harcourt, Nigeria \\ *Correspondence: Faculty of Law, University of Calabar, Calabar, Nigeria. Tel: 234-803-682-2222. E-mail: \\ aloboenie@yahoo.com
}

Received: September 21, 2017 Accepted: October 18, $2017 \quad$ Online Published: November 30, 2017

doi:10.5430/wjss.v5n1p36

URL: https://doi.org/10.5430/wjss.v5n1p36

\begin{abstract}
Consumer credit is debt that is obtained by persons who intend to spend the money immediately. Assessing consumer credit tells us imperative things about our economy. If consumers have the capacity to borrow effortlessly and refund those debts on time, then the economy should be stimulated and we will have growth. Consumers are the instrument and brainbox of the economy, when credit is unavailable, consumers will face foremost complications in borrowing. In this circumstance, consumers would consume less since they have less access to credit. For this reason, manufacturers will sell less, and produce less. The importance of a viable consumer credit system cannot be over emphasized. This paper hypothesizes that certain identified factors militate against the development of a strong consumer credit system in Nigeria. It examines and analyses these challenges and exposes their negative roles in the development of a strong consumer credit system. It focuses on strategies that can improve consumer access to credit facilities and concludes that there is need for a paradigmatic change. It therefore makes recommendations that can challenge Nigerian policy makers to improve on, or evolve a stronger consumer credit system.
\end{abstract}

Keywords: consumer credit, money lending, loan

\section{Introduction}

Lending in Nigeria and indeed other developing countries like Nigeria presents unique challenges. Nigeria for instance is the most populous country in Sub-Saharan Africa with a World Bank population figure of about 168.8 million. Poverty in Nigeria remains significantly high with $65 \%$ of its inhabitants living on below $\$ 1$ daily. There is income inequality which gets worse by the day. This leads to differential access to infrastructure and amenities. High unemployment rate renders personal income even more divergent. Less than $25 \%$ of Nigerians hold bank accounts and only a small fraction of that has access to credit among the banking population in Nigeria (Popoola, 2009). A 2015 World Bank data puts the total credit relative to GDP in Nigeria to be 14.2 percent, while the world average is 128.8 percent. Countries like Switzerland, Thailand and the United Kingdom have 172.6 percent, 151.3 and 134.1 respectively (World Bank, 2017). This shows that access to consumer credit in Nigeria is extremely low. Poor access to banks and bank credits is however not purely a Nigerian problem. It is a problem that is common with developing economies (Mckinsey, 2009). This, coupled with little or no information to evaluate the credit worthiness of individuals, frustrates credit penetration.

Even though the Nigerian credit system is still evolving, Nigeria has an array of financial institutions with 22 commercial banks according to a latest Central Bank of Nigeria's latest figures. It has about 949 microfinance banks, over 100 primary mortgage institutions, discount houses, and a number of some special purpose financial institutions, (Popoola, 2015). In spite of this, the percentage of adults with bank accounts is abysmally low as earlier stated. Consequently, the percentage of Nigerians who have access to formal bank credit is also abysmally low, making consumer credit inevitable for this group of Nigerians.

The idea of consumer protection in Nigeria is a fairly new phenomenon (Kanyib, 2005). Nigeria for instance has no Consumer Protection Act, no Consumer Credit Act and no effective and functional credit bureaus. These and more 
consumer protection legislation exist in countries like the United Kingdom, United States and even South Africa. What Nigeria has is a Consumer Protection Council Act of 1992, which provides more of an administrative framework for the regulation of consumer issues. The practical implication of this is that, there is no legal or regulatory framework for the operation of a formal consumer credit system in Nigeria, so consumers are easily cheated while credit providers are reluctant to extend credit. The need to develop effective and dynamic consumer credit laws to aid the highly industrious and dynamic Nigerian population cannot be over emphasized. The few normative instruments like the Hire Purchase Act 1965, The Money Lenders Laws in different states of the Federation and the Pawnbrokers Laws of different states, have all lost touch with reality and some have almost completely out-lived their usefulness as consumer credit instruments. Their provisions will be exposed here so as to help underscore their unsuitability. The sordid picture painted above affects the women folk even more, due to the nature of the legal, regulatory, and socio-cultural barriers in the Nigerian society. In this connection, the numerous challenges faced by female entrepreneurs can also be linked to the inferior status of women in many African societies, their underestimation as economic agents, as well as gender bias embedded in tribal and cultural norms.

Although a growing number of policies and programs are arising to address the needs of the growing number of women business owners and their enterprises worldwide, access to finance is still the single biggest obstacle facing women entrepreneurs particularly in Nigeria. It is therefore apposite to state that Nigerian female entrepreneurs are particularly constrained by their weak financial base and lack of collateral. This work therefore intends to examine their inability to access consumer credit and the factors, militating against their access to credit facilities. A corollary of this is that, the state of consumer credit in Nigeria leaves much to be desired. It is for this reason that attempt will be made to proffer reasons for the slow pace of consumer credit development and growth in Nigeria and the challenges therein.

\section{Definition and Scope of Consumer Credit}

\subsection{Credit}

Credit may be defined as a situation where one party provides resources to another party who has no resources to reimburse the first party immediately, but instead arranges to pay or return those resources at a later date. It includes all forms of differed payments. The resources provided may be financial, or they may consist of goods or services. The credit concept can be applied even in a barter economy. Broadly speaking therefore, credit takes two forms: loan credit and supply/sale credit. Loan credit is credit extended by payment of money to the debtor, or to a third party at the debtor's request, upon terms that the debtor is to make repayment. Supply credit is simply the deferment of the debtor's obligation to pay the price of goods or service supplied/rendered. In practical terms therefore, loan credit involves repayment of an advance while supply credit involves deferment of payment (Essien, 2012). The English Consumer Credit Act 2006 defines credit as a cash loan and any other form of financial accommodation where the debtor is allowed time to pay. It includes a hire purchase agreement.

\subsection{Consumer Credit}

The Black's Law Dictionary (Black, 1990) defines it as short term loans given to individuals for the purchase of consumer goods and services. It can also be defined as a short term loan made to enable people purchase goods and services primarily for personal, family or household purpose. It is a short and immediate term loan used to finance the purchase of commodities for personal consumption. The Barons Banking Dictionary defines it as a credit extended to individuals for personal or household use, rather than for business. Broadly defined, consumer credit includes all forms of installmental credit, other than loans secured by real estate (mortgages) or open ended credits like credit cards. This definition is apt. The loans may be supplied by lenders in the form of sales credit. Consumer credit usually comes with a higher rate of interest than business loans. Most traditional forms of consumer credit like car loans have standard monthly payment and fixed repayment schedules with fixed or varied interest rates. Consumer credit enhances consumer satisfaction as it enables consumers to enjoy services of goods sooner than they otherwise would have done. It enables consumers who are unable to save money for the purchase of goods and services, to enjoy such goods and services if they are able to keep their contracts with their creditors.

The originator of a credit is the person or company who originally extended the credit, while the holder is the individual or business who obtained the debt at a discounted price in order to collect payment at a subsequent time. A car dealer who gives out a car to a customer on credit is an originator of credit. Such credit facilities are sometimes assigned to banks and other financial companies who become credit holders. Two types of companies are actively involved with consumer credits. The first is the small loans company. This type of company as an originator gives 
loans to consumers directly, because it has direct contact with them. The second is the sales finance company, which purchases and holds consumer installment debts. These companies play vital roles in empowerments and economic development thereby ensuring a credit economy so that citizens can enjoy improved living standards, good housing systems, and holidays. A credit economy in Nigeria will simply stimulate a lot of buying and selling. This will in turn increase productivity, boost employment by the production companies and this will affect the economy positively as there would be more savings. In simple terms, consumer credit is debt that is taken on by individuals who aim to expend the monies immediately. A person who borrows money to buy a bicycle or use a credit card to pay for a meal, is indulging in consumer credit. In other words, the operating intention for the debtor is to consume. However, if one borrows money for investment purposes, to commence a business enterprise, or to acquire a home, such a person is not using consumer credit. The whole point of consumer credit is to consume something today that you would otherwise not have been able to afford until later.

\section{Background to Consumer Credit in Nigeria}

As already noted, the need for consumer credit facilities arises from the inability of the consumer to make immediate payment for goods and services he needs either personally or for his family's use. This was seen as a sign of poverty. According to Essien, this was why the debtor in olden days was looked down upon the world over. He adds that from the $18^{\text {th }}$ and $19^{\text {th }}$ centuries, there were moral prohibitions with regards to the principles of credit and dislike for it was expressed in moralistic tones, especially by the wealthy and middle classes. Proverbs like "Better to go to bed without supper, than to rise in debt", or "He that borrows must pay again with shame and loss", etc. aptly exemplify the prevailing attitude towards consumer credit facilities at the time. With the advent of Christianity, the Holy Bible was immediately employed in this unwholesome practice of discouraging consumers from taking credit facilities. Certain verses in the Bible were thus quoted out of context; "...you shall lend to many. But you shall not borrow" "... it is more blessed to give than to receive", the rich rules over the poor, and the borrower is servant to the lender". These negative adaptations of biblical verses coupled with the very popular adage that the hand of the giver is perpetually on the head of the receiver seem to have influenced the negative attitude towards consumer credit in Nigeria at the time.

The early forms of credit involved the borrowing of some commodities which were used as currency at that time. The local currencies in existence in Nigerian communities before the European trade is said to have consisted of brass rods, manilas, copper wires and cowries (Faloa, 1987). Manila for instance is speculated to have been first introduced into Nigeria in the $15^{\text {th }}$ century by the Portuguese traders (Ekpo, 1979). The English traders who came later just adopted this mode of payment. It seems cowries were in use in Nigeria long before the Manila (Batuta, 1929). According to (Hiskett, 1966) it was the Malian cowries that must have found their way to Nigeria. Gin, gold dust, tobacco, salt and iron bars were also used in credit transactions in Nigeria. Though iron bars were more favoured in Southern Nigeria. British currency was introduced into Lagos (Nigeria) in 1881 and in 1904, the importation of cowries into Nigeria was abolished. In 1948, the Nigerian Legislative Council stopped the exchange of Manilas for British currencies. After this, the British currencies became the only means of credit transactions until 1973 when the Naira and Kobo was introduced by the Nigerian government.(Essien, 2012). In the Southern part of ancient Nigeria, the Ekpe and the Ekpo societies were used to enforce credit obligations. These societies were so effective such that some European traders were induced to join the Ekpe society in the $19^{\text {th }}$ century. This enabled them to give credit to African traders with the confidence that it could be recovered (Holman, 1840). As the use of consumer credit began to grow and became popular, there was also a change of attitude towards its use and role in the credit system generally. Today, the view of consumer credit as a system for the poor is no longer popular.

In a more commercial historical perspective, when banking commenced in Nigeria at about 1892, the need to develop consumer credit products was not imperative as few banks then were in operation. The deregulation of the financial sector gave room for the formation and licensing of numerous new command and merchant banks. With this came aggressive competition among the commercial banks, which finally led to the introduction of new consumer credit products in Nigerian commercial banks.In spite of this, consumer credit remained nascent and undeveloped with consumers being unsatisfied with the credit products introduced in the financial market (Monye, 2003).

\section{The Challenges of Evolving a Strong Consumer Credit System in Nigeria}

The need for a potent consumer credit system cannot be overemphasized. It would stimulate economic growth, as 
there is a direct relationship between consumer credit and Gross Domestic Product (GDP) growth. A strong consumer credit culture and banking system would undoubtedly strengthen financial intermediation as this enhances the capacity to mobilize and deploy savings to critical sectors of the Nigerian economy. The challenges of evolving a strong consumer credit system in Nigeria are multifarious and multidimensional. The consumer credit system in Nigeria is largely under-developed. For this reason, only few Nigerians like those in the upper class can access such facilities, and for selected items only. Moreover, the extra-judicial methods usually resorted to for debt collection and recovery discourage prospective customers. Weak attempts by the government has been stymied by several factors ranging from weak and obsolete laws, cultural barriers and at times complete lack of the legal infrastructure to back up governmental policies and guidelines. In spite of the enviable array of financial institutions in Nigeria, extension of consumer credit to Nigerians is still very low. The question that may be asked here is why this is so? (Popoola, 2010) lists the factors impeding the development as low income, unreliable macroeconomic statistics, high roles and weak rating systems for individual and corporate organizations. According to him, most banks in Nigeria prefer to grant credit to the elites and highly placed individuals. He concludes that if the credit system is going to help in alleviating poverty, then the banks and other credit organizations will have to make themselves accessible to the less privileged in the society by making their rates affordable and conditions for accessing credit less cumbersome. These observations have undoubtedly highlighted some of the drawbacks.

In addition to the above, archaic and obsolete laws that do not fit into modern day financial transactions still exist and are still being used in Nigeria. These include Laws like the Money Lenders Laws of different states in Nigeria, the Pawnbrokers Laws of different states and the Hire Purchase Act of 1965. Cultural barriers too, play important roles in impeding access to credit, especially for women. These and other factors are examined hereunder. On the whole, we have identified and discussed infra normative, institutional and social factors encumbering the development of consumer credit in Nigeria.

\section{The Money Lenders Law 1939 Cap M7 Laws of Cross River State of Nigeria 2004}

In Nigeria, the Money Lenders Law exists as state laws in different states of the Federation. Money lending is a very common form of consumer credit in Nigeria, and had been in existence in Nigeria even before the existence of any formal regulation (Essien, 2012). The practice evolved and became commonly practiced by Nigerians because few Nigerians have access to formal forms of credit (Popoola, 2009). The need, therefore, arose to breach the gab created by this inaccessibility to formal credit especially for those who needed small loans for consumer products (Eja \& Bassey, 2010). This came with its attendant problems as shylock money lenders had all sorts of unfair contract terms with excessive rates of interest, hence the need for some form of regulation by the state. But how useful is this 1939 law in present day Nigeria as a consumer credit instrument? The law attempts to regulate the practice of money lending in Cross River State. Thus, by sections 5 and 6 of the law, a person intending to do business as a money lender must be a fit and proper person in character and disposition, attested to by a magistrate having jurisdiction in the area in a certificate. This is a precondition for grant of a money lenders license. The license, by section 2 is given to a person personally and not a body of persons and on each business address. The law attempts in Section 10 to set out the form of the contract. This is expected to be followed strictly otherwise the contract is not enforceable by the lender. For instance, the contract must be in writing and signed by the lender before the money is lent (Oloyede, 1999). By Section 17, the money lender must issue receipts and keep a book of record. A breach of this requirement renders the transaction unenforceable by the money lender, and in addition the money lender will be guilty of an offence and liable to a fine of Twenty Naira ( $\$ 20)$. Section 11 regulates the rate of interest, while Section 23 forbids inducement to borrow through false and misleading statements.

This law is commendable in attempting to protect the interest of consumer credit seekers in the state. But with regard to the amounts charged as penalties for defaulting, this law appears to be a toothless bulldog. For instance, by section 2, the yearly fee for a money lender's license is Ten Naira ( $\$ 10)$. According to section 3 (d), Penalty for failure to obtain a license is Two Hundred Naira (\$200) for both individuals and corporate organizations and One Thousand Naira $(11,000)$ for continuous breach by a corporate organization. The penalty for charging unauthorized interest is One Hundred Naira ( 100 ) in respect of each loan. These are a few of the laughable monetary fines which in modern times cannot deter offenders. Also by Section 12(2) the prosecution for charging unauthorized interest cannot be instituted except by or with the consent of the Attorney General of the state. One wonders why this is so when the Attorney General as the Chief Law Officer of the state is so busy. The utility of this law may be hampered by this provision due to undue delay. In Nigeria, it is common practice for the police to prosecute even more serious cases (Eja \& Bassey, 2010). The law needs to be reviewed in order to bring it in line with modern realities. The 
inadequacies and encumbrances contained in the Cross River State Money Lenders Law are replicated in the laws of other states in Nigeria. For instance, the provisions of the Money Lenders' Law Cap. 84, Laws of Eastern Nigeria 1963 applicable in all Eastern States of Nigeria are in pari material with the Money Lenders Law of Cross River State. In fact, prior to 1990, money lending was regulated concurrently by the Federal Government of Nigeria and by the various State Governments through the Moneylenders Act, 1958 and the Moneylenders Laws of various States. However, the Moneylenders Act has been repealed, leaving the regulation of money lending to the Moneylenders Laws of various States in Nigeria. Their provisions are basically the same.

\section{The Pawnbrokers Law 1917, Cap P3, Laws of Cross River State of Nigeria 2004}

Pawnbrokers can be said to be a practice where one person called the Pawner borrows money from another called the pawnee, whereby the pawner deposits or pledges his personal property with the pawnee as security for the loan (Black, 1990). Pawnbroking is a traditional practice in Nigeria. Traditionally, anything can be pawned. This includes land, economic trees and personal items. Usually the item is kept for a specified period within which the pawner is expected to repay the loan at an agreed interest and retrieve his item upon repayment. However, where he fails to pay within the stipulated period, the Pawnbroker is entitled to sell the item in order to recover his money. Typically, pawning does not connote transfer of title but merely conveys a possessory right to the pawnbroker.

The Cross River State Pawnbrokers law is limited in scope. Thus by Section 5, it applies to loans not exceeding Forty Naira ( $\$ 40$ ). This amount is absolutely ridiculous in modern day Nigeria. It is doubtful if any volume of credit transaction will fall within this limit. In the United Kingdom (UK) for instance, the original limit of Five thousand Pounds $(£ 5,000)$ set by the Consumer Credit Act 1974 was later increased to Twenty-five Thousand pounds $(£ 25,000)$. Under the UK Consumer Credit Act 2006, there is no upper limit. This is an Act that is obviously dynamic. The Cross River State Pawnbroker's Law in section 11 and 12, expects pawners to even pledge Articles worth One Naira ( $\$ 1)$ and below. One wonders the nature of such Articles. By Section 13, the sale of pawned Articles above One Naira ( $\$ 1$ ) is to be sold by public auction. This means that any pawned Article worth Two Naira ( $\$ 2$ ) must be sold by a public auction. In Nigeria today, one can hardly see an Article worth only Two Naira (\$2). When the cost of the good in issue is compared with the cost of organizing a public auction, one cannot help to conclude that the law has lost touch with reality.

Under section 26, a person who unlawfully pawns the property of another is guilty on summary conviction to a fine of Ten Naira ( $\$ 10)$. A person who refuses to give or is unable to give a good account of how he came by the Article he desires to pawn is liable to a fine of Twenty Naira (\$20) under section 27. It is however consoling that by Section 27(2), the pawnbroker can hand a pawner to the police if he reasonably suspects that the Article intended to be pawned is stolen. However, the New Zealand position is preferable. Under section 35 (1) New Zealand Pawnbrokers Act, 1908, where a person who pawns is unable to give adequate information or refuses to give a satisfactory account of how he came by the Article, or has given a false information or false information of his place of abode, or the pawnbroker reasonably suspects that the Article is stolen, he may seize and detain the person and Article and deliver same to the police immediately. The limited scope of the transaction, together with the penalties contained in the law, is enough to condemn the law as being unsuitable in modern day Nigeria.

\section{The Hire Purchase Act 1965}

Hire purchase transactions in Nigeria are governed by the hire Purchase Act, Cap 44, Laws of the Federation of Nigeria 2004. This is a federal law and so it operates in all the states in Nigeria. Even though the formal form of hire purchase is fairly recent in Nigeria as the first formal law is the 1965 Act, the practice had been in existence in different parts of Nigeria in its traditional nature (Okany, 2009). The term is commonly used to refer to contracts for the hire of chattels with an option to purchase. It can also be used for an agreement to purchase chattels by instalments but which is accompanied by a term that the property can only pass upon the payment of all instalments (Halsbury's). In Nigeria, the Hire Purchase Act was enacted to curb the inadequacies of Common Law. Prior to the emergence of the Act, Common Law governed hire purchase transactions and it had no prescribed uniform format (Okany, 2009). This enabled hirers to insert harsh and stringent conditions in the agreements. The Act, therefore, was intended to curb the injustices prevalent before the emergence of the Act. As commendable as the Act is in curbing the injustices of the past, especially in the recovery of goods by the owner, it is limited in scope. Section 1(a) limits the volume of transaction to Two Thousand Naira $(\mathbb{N} 2,000)$ only. However, it excludes agreements in respect of motor vehicles. This has been interpreted to mean that transactions not covered by the Act are still governed by the 
Common Law (Achike, 1985). It is here being suggested that the scope of transactions covered by the Act should be expanded to meet modern day realities.

\section{The Absence of a Concise Consumer Credit Act and other Consumer Credit Protection Laws}

The Nigerian consumer needs more protection than what is currently the case. Nigeria does not have one concise, unified, comprehensive and recognizable law for the protection of consumers like a Consumer Credit Act. This means that there is lack of effective regulation, control and monitoring of matters relating to consumer credit. Thus, different laws like those already discussed exist and operate as consumer credit regimes. There is, therefore, need for a unified legislation like a Consumer Credit Act. This was hitherto the case in England before the emergence of the Consumer Credit Act 1974 which was later replaced by the Consumer Credit Act 2006. The Act swept away the piecemeal legislation/regulation and replaced them with a single code (Lowe \& Woodroff, 2008). Equally, the South African Consumer Credit Act 2005, eliminates the piecemeal approach to consumer transactions in South Africa. It encourages fair and responsible credit transactions under section 4 (1) and creates the National Credit regulator to enforce compliance with the Act, in addition to the regulation of activities of credit bureaus in sections 43 and 70 . The United States Consumer Credit Act 1968, standardizes and encourages honest credit transactions. In addition, the United States has other interesting consumer credit laws like the Fair Credit Reporting Act which attempts to ensure accurate reporting of consumers' personal information (Krulick, 2014) and the Fair Debt Collection Practice Acts 1996. The provisions of the latter are interesting because what it prohibits are common occurrences in Nigeria. By this Act, a debt collector may not without prior and express consent of the consumer to the lender, contact or discuss the debt issue with the consumer at places and times considered to be inconvenient to the consumer. It prohibits debt collection through harassment, abuse, threat of violence or through unfair and unconscionable means.

There are no similar legislations in Nigeria and so Nigerian consumers grapple alone with all manners of difficulties. What Nigeria parades in this direction is a Consumer Protection Council Act 1992. What could have been a National Consumer Credit Regulatory Commission Act is still pending in the National Assembly since 2009. This dilemma may have informed the CBN to attempt to fill the gap in spite of the lack of legislative support. Thus in 2010, it introduced supervisory frameworks for Commercial and Micro-finance Banks. It prohibited universal banking and introduced tiered banking in an attempt to shield bank deposits from broad risks. In 2011, it introduced Islamic banking which is a non-interest financial service. Currently, the Consumer Protection Council which has no mandate to deal with Consumer Credit issues, forwards all unresolved financial complains to the CBN for resolution (Cornel and Kevin, 2014). It has also introduced measures to address card and Automated Teller Machine (ATM) fraud. Consequently, all financial institutions in Nigeria are mandated to have consumer help desks to handle consumer complaints within a specified period and to give periodic reports to the CBN. Nigeria needs to salvage the CBN from the crisis management it has voluntarily undertaken, so it can concentrate on its traditional roles.

\section{Women and Access to Consumer Credit in Nigeria}

The Nigerian women like most African women face a lot of gender related challenges. Access to consumer credit facilities constitutes one of these challenges. Women in Nigeria battle with a lot of socio-cultural constraints coupled with non- supportive policies and business environment as well as the age long myth which unfortunately women themselves tend to accept that men are superior to them (Nkamnebe, 2010). These tend to impact negatively on their mental readiness to take on risks and roles associated with consumer credit. The disadvantaged position of the Nigerian women has been recognized and criticized by (Ajibola, 1993) when he said:

In our society, it has long been fashionable to treat women as merely a God-given appendage to man... It has always been conceded that law can and is in fact often deployed to perpetuate the attitudes of society. Accordingly, our statutory laws are littered with provisions and principles, which remotely and tangentially constitute women into a disempowered group.

The societal disempowerment of women is the basic reason why women in Nigeria cannot meet the terms and conditions of consumer credit grantors. This societal attitude also places the bulk of the nation's resources under the control or men, with just a negligible number of women having access to same (Sofo \& Toni, 2003). The economic control of resources by men is not in tandem with the fact that in Africa, women produce $80 \%$ of the food for the continent. In spite of the production input by women, they receive less than $10 \%$ of the earnings and credit available 
to small farmers. The factors which militate against women's ability to access and utilize credit facilities include high illiteracy rate, low-socio-economic status and high interest rates on consumer credit. Also women are traditionally brought up to feel that they are not meant to bear risks, they are thus, unable to take on risks associated with the different types of consumer credit. In addition to this, women traditionally are discriminated against in land inheritance. Therefore, men basically are the custodians of landed property. Half hazard attempts by governments to assist women to access consumer credit have equally been hampered by the high illiteracy rate among the women and even cultural barriers.

Nigeria's National Gender Policy which purports to support the United Nation's 35\% affirmative action for women's empowerment has no impact on the Nigerian woman. Available statistics show that only 9 out of the 109 senators are women and only 27 women out of the 360 House of Representative members. The figures in the 36 Houses of Assembly are even worse as there are only 54 women out of 990 members and no female governor currently. The marginalization impacts negatively on women's economic wellbeing and consequently, their ability to meet the stringent conditions set by credit providers. These factors militate against women's full involvement in available consumer credit system and invariably, constitute serious draw backs towards the development of a strong credit system in Nigeria. To get out of this, Financial institutions should be made to de-emphasis the possession of landed property as security before granting credit facilities. This places the women and other low income Nigerians in a disadvantaged position in the absence of a Consumer Credit Act.

\section{Lack of Effective Credit Bureaus}

No economy can witness serious upsurge in consumer credit without a strong and reliable credit information sharing platform. The observation by Popoola that banks and other financial institutions only grant credit to the elites while ignoring the less privileged members of the public raises the issue of the lack of an information data-base. The Central Bank of Nigeria (CBN) in an attempt to solve this problem established a Credit Risk Management System (CRMS) or Credit Bureau (CB) and provided guidelines for its operations in 2008. This was supposed to gather information on consumer's credit history from various sources so as to assist in assessing the credit of borrowers. (Popoola, 2010). The availability of an effective CB encourages responsible financing, improved access to credit with lower interest rates for good borrowers. It reduces information asymmetries between lender and borrower and improves credit risk monitoring.

The presence of a viable CB tends to encourage consumers' access to available credit facilities. This is being suggested by a World Bank survey based on 5,000 firms in 51 countries. This shows that $49 \%$ of small firms reported high financing constrains in countries without a CB and $27 \%$ in countries with CB. Also, while only $28 \%$ had a probability of obtaining a bank loan for a small firm in countries without a $\mathrm{CB}, 40 \%$ had such probabilities in countries with $\mathrm{CB}$. A functional $\mathrm{CB}$ provides an industry wide information repository on the credit profiles of consumers, thus enabling credit providers to make informed decisions. This means that with a CB one does not have to be formally employed or have physical assets as collaterals before being able to assess credit facilities and the incidences of bad and nonperforming loans which led to the collapse of many banks in Nigeria would be reduced. (Komolafe, 2009) insists that the CBN must put enabling legislation in place to enforce its guidelines so as to reduce the incidences of nonperforming loans.

The CB in Nigeria is plagued with the problem of lack of legal framework to enforce its guidelines or its operations. A bill for an Act to provide for such a framework is still pending in the National Assembly since 2009. Information collection from consumers in Nigeria may encounter constrains if not backed by law. Commenting on this, (Popoola, 2010) emphasized that Nigerians are highly and naturally skeptical about giving out their personal information. Such enquiries may be mistaken as information for taxation or for diabolical purposes. The CBN's guidelines in 2008 which made consumer's consent necessary before his personal details are submitted to a CB, seemed to have worsened the issue. This is so because there is no law which makes it mandatory for the consumer to give the information when properly sought. There is therefore the need to create strong, useful and effective credit bureaus to act as databanks for information on consumers. This will reduce incidences of bad debts from bank portfolios and consequently incidences of collapsed financial institutions. It will also make access to credit less cumbersome and thus more attractive to consumers.

\section{Lack of a Standardized National Identification}

Consumer credit cannot flourish in an environment where the identification of the consumer is problematic. 
Consumer identification is key to consumer credit transactions. Lenders need to know who they are dealing with. Nigeria is only currently experimenting with a uniform identification of her citizens. Previous attempts had been unsuccessful and one hopes that this one will achieve its utility. Currently, various forms of identification of customers are employed by lenders. Identity cards from employers, international passports, permanent voters cards and drivers licenses are all used. Banks even go to the ridiculous extent of asking for physical description of residential houses and production of utility bills. This could have been unnecessary with a standardized and recognizable identification system.

\section{Illiteracy}

In spite of the fact that a large percentage of Nigerians are highly literate, Nigeria still has a huge percentage of illiterate people. This could induce unconscionable lenders to exploit their illiterate customers. This set of consumers could be made to sign documents which are one sided and which impose undue burden on them. Therefore Nigeria needs to address its illiteracy problem if it must advance with consumer credit. Sadly, the illiteracy rate in Nigeria is still high in spite of numerous government programmes to encourage Nigerians of all strata to go to school. In this connection, Nigeria needs to improve on the illiteracy figure, the figure given by the Nigerian Acting Minister of Education in 2015 is shameful and a sad commentary on the state of education in Nigeria. The government needs more political will in order to actualize its numerous educational programmes meant to improve the literacy rate in Nigeria.

\section{Concluding Remarks and Recommendations}

This work was an exposition of the factors militating against the institution of a strong consumer credit system in Nigeria. It assessed the extent to which each identified factor affect access to consumer credit in Nigeria. It was observed that those inadequacies seriously affected the establishment of a strong consumer credit structure in various ways. In addition to the above identified hindrances, we recommend the Solidification of consumer credit risk management by Nigerian banks. Evolving innovative techniques to evaluate credit risk, such as mobile phone procedure or bill disbursement data, is paramount as more persons and trades with restricted credit potential need monetary facilities. This is known as a crucial apprehension by bankers in borderline trades, where the economies are less unwavering and where numerous consumers are novel to funding and therefore have no credit histories. Banks in these markets should also consider adapting credit products to match the needs and lives of less affluent customers. (Young, 2012). The need for robust credit risk valuation is acknowledged as a strategic primacy by some but will need to be a focus across all banks if they are to avoid repeating the mistakes of the past (Young, 2012). Besides, Spending and investing in technology will give a decisive impetus to small scale consumer credit banking in all markets. Technology will be a foremost dynamic in attaining firsthand retail customers without the cost of creating wide-ranging branch networks, and refining associations and cross-selling projections with current customers.

It is distillable from our research that Nigeria needs one unified Consumer Credit Act that may be fashioned after the 1974 English Credit Act as amended in 2006. This will incorporate all the Acts and laws governing different aspects of consumer credit and also bring the law in line with modern day realities. The English Act is imperative and key to effective consumer credit development in the following ways:

i. $\quad$ The Act makes consumer king;

ii. The creation of institutional framework with a national character to promote development of an accessible credit market;

iii. The Acts, ensures a wide coverage of credit to disadvantaged persons, low income persons and communities, remote, isolated or low density populations and communities;

iv. It makes provisions to prohibit reckless lending;

v. It harmonizes existing laws of consumer credit;

vi. It made possible the replacement of the extortionate credit test with an unfair relationship test which enables debtors to challenge unfair relationships with creditors and the courts have wide discretion to re-write agreements which are unfair to the debtors;

vii. It provides for dispute settlement rather than dispute enforcement;

viii. It provides for regulation of interest and fees in all agreements, including micro-loans. 
ix. It provides for credit policy and certain consumer's rights;

$\mathrm{x}$ It creates conducive environment for competition to check monopolistic tendencies of credit providers;

xi. Provisions of pre-agreements disclosures as a device to protect credit consumers from entering into agreements with excruciating terms, limiting terms and unfair terms.

Also, the Consumer Protection Council should be given more powers to deal with consumer credit providers whenever the need arises. As it is, the Council appears to be operationally handicapped. Consumer Courts should be established both at the State and Federal levels by the relevant legislative houses. These will be Courts of special jurisdiction. The existence of the Courts will also help to increase awareness of consumer issues including consumer credit issues all over the federation. Besides, conscious efforts should be made by the Nigerian government to institutionalize a strong and enduring consumer credit regime as this will bring the much desired development in consonance with the Millennium Development Goals (MDGs).

The synopses of our recommendations for effective consumer protection in the Nigeria credit system are:

i. Harmonization of all existing consumer credit laws into one comprehensive legal framework for a unified consumer credit act applicable throughout the country.

ii. An institutionalized competitive legislation is advocated for the credit environment.

iii. Consumer education on credit matters.

iv. An effective and efficient judicial system for the enforcement of the consumer credit legislation is advocated.

v. Consumer credit availability should be devoid of discrimination on grounds of sex, status in the society and religion.

vi. Banks and other financial institutions to be encouraged and supported by the state to provide consumer credit at a single digit interest.

vii. An effective enforcement mechanism including dispute resolution system.

\section{References}

Achike, O. (1985). Commercial Law in Nigeria, p. 352,

AjIbola, B. (1993). Law Reform in a Military Era; Nigerian essays in jurisprudence. Lagos, M. I. J. Pub. Ltd. p. 399.

Batuta, I. (1929). Travels in Asia and Africa, 1325-54. London, cited in Essien, op.cit at p. 15.

Black, H. C. (1990). Black's Law Dictionary, West Group, $6^{\text {th }}$ ed.

Eja, E. E., \& Bassey, E. (2010). Money Lending Law and Regulation of Consumer Credit in Nigeria."' Retrieved from http://www.ajoliinfor/index/ph/.naujij/articledownload82406/72558.accessed.13/2/2017

Ekpo, E. (1979). "Nigeria and the Evolution of Money" CBN and Dept. of Antiquities, Lagos, p. 59.

Essien, E. (2012). Law of Credit and Security. Uyo: Toplaw Publishments Ltd, p. 4

Faloa, T. (1987). Nigeria and Britain: exploitation or development? London and New Jersy, Zed. Books Ltd., p. 14.

Hiskett, M. (1966). "Materials Relating to the Cowries Currency of the Western Sudan", Vol. xxix, Bulletin of the school of Oriental and African studies, pp. 339-3666 cited in Essien, E. op.cit.

Kanyib, B.B. (2005). Consumer Protection in Nigeria, Law, Theory and Policy. Rekon Books Ltd., p. 2

Komolafe, B. (2009). "Legislation Hinders credit Bureaus Momentum" Vanguard, Sept. Retrieved from http://www.crservicespic.com/legislation-hinders-credit

Krulick, A. L. (2009). Consumer Credit Protection Act; Laws protecting Consumer Rights. Retrieved from $\mathrm{http} / / / \mathrm{www} . \mathrm{deb}$. org/credit/yourconsumer.rightsprotection-act2014

Monye, N. (2003). Law of Consumer Protection. Ibadan: Spectrum Books Ltd., p.11

Okany, M. C. (2009). Nigerian Commercial Law. Africana First Publishers Inc., p. 634

Popoola, A. T. (2010). "The Challenges of a Strong Credit System in Nigeria” Credit Awareness. Retrieved from http://www.creditawareness.nigeri.com/nes-sph.p 
Popoola, A. T. (2014). "The Challenges of Financial infrastructure in Nigeria", NDFF. Retrieved from http://www.nigeriadevelopmentandfinancial forum.org/policydialogue.

Sofo, C., \& Toni P. (2003). Measuring poverty in Nigeria. Oxford, Oxfam Press, p. 52. 